\title{
Erythrocytes as a Model for Heavy Metal-Related Vascular Dysfunction: The Protective Effect of Dietary Components
}

\author{
Rosaria Notariale $^{1}$, Rosmara Infantino ${ }^{2}$ D, Enza Palazzo ${ }^{2}$ and Caterina Manna ${ }^{1, *(D)}$ \\ 1 Department of Precision Medicine, School of Medicine, University of Campania "Luigi Vanvitelli", \\ 80138 Naples, Italy; notarialer@gmail.com \\ 2 Department of Experimental Medicine, Division of Pharmacology, University of Campania "Luigi Vanvitelli", \\ 80138 Naples, Italy; rosmainfantino@gmail.com (R.I.); enza.palazzo@unicampania.it (E.P.) \\ * Correspondence: caterina.manna@unicampania.it
}

check for updates

Citation: Notariale, R.; Infantino, R.; Palazzo, E.; Manna, C. Erythrocytes as a Model for Heavy Metal-Related Vascular Dysfunction: The Protective Effect of Dietary Components. Int. J. Mol. Sci. 2021, 22, 6604. https:// doi.org/10.3390/ijms22126604

Academic Editor: Christy C. Bridges

Received: 27 May 2021

Accepted: 18 June 2021

Published: 20 June 2021

Publisher's Note: MDPI stays neutral with regard to jurisdictional claims in published maps and institutional affiliations.

Copyright: (c) 2021 by the authors. Licensee MDPI, Basel, Switzerland. This article is an open access article distributed under the terms and conditions of the Creative Commons Attribution (CC BY) license (https:/ / creativecommons.org/licenses/by/ $4.0 /)$.

\begin{abstract}
Heavy metals are toxic environmental pollutants associated with severe ecological and human health risks. Among them is mercury $(\mathrm{Hg})$, widespread in air, soil, and water, due to its peculiar geo-biochemical cycle. The clinical consequences of $\mathrm{Hg}$ exposure include neurotoxicity and nephrotoxicity. Furthermore, increased risk for cardiovascular diseases is also reported due to a direct effect on cardiovascular tissues, including endothelial cells, recently identified as important targets for the harmful action of heavy metals. In this review, we will discuss the rationale for the potential use of erythrocytes as a surrogate model to study $\mathrm{Hg}$-related toxicity on the cardiovascular system. The toxic effects of $\mathrm{Hg}$ on erythrocytes have been amply investigated in the last few years. Among the observed alterations, phosphatidylserine exposure has been proposed as an underlying mechanism responsible for $\mathrm{Hg}$-induced increased proatherogenic and prothrombotic activity of these cells. Furthermore, following $\mathrm{Hg}$-exposure, a decrease in NOS activity has also been reported, with consequent lowering of NO bioavailability, thus impairing endothelial function. An additional mechanism that may induce a decrease in NO availability is the generation of an oxidative microenvironment. Finally, considering that chronic $\mathrm{Hg}$ exposure mainly occurs through contaminated foods, the protective effect of dietary components is also discussed.
\end{abstract}

Keywords: cardiovascular diseases; endothelium; erythrocytes; heavy metals; mercury; nutrition; oxidative stress; polyphenol

\section{Introduction}

Heavy metals are a group of ubiquitous and non-biodegradable pollutants widely distributed in the environment. Heavy metal pollution of the environment results not only from natural sources such as volcanic activity and fossil fuels, but also from numerous agricultural, medical, industrial, and technological human activities [1,2]. Exposure to heavy metals in humans occurs mainly from contamination of water, soil, and food. The exposure to low levels of heavy metals in the general population is widely recognized while massive exposure affects specific subpopulations under certain circumstances, especially occupational ones. Exposure to heavy metals is associated with both short-term adverse effects and long-term diseases such as cancers, immune system dysfunctions, neurocognitive impairments, behavioral abnormalities, hormonal and metabolic dysregulation, and specific organ damage [3-5].

It should be emphasized that living systems interact in the environment not only with a single heavy metal [6-9] but more often with a cocktail of compounds that can have synergistic adverse effects on the organism [10-13]. Preclinical and clinical studies have investigated the toxicity of mixtures of the main heavy metals [14] that pollute the environment such as lead, mercury $(\mathrm{Hg})$, chromium, cadmium, and arsenic on various organs, systems, or conditions [15-19]. A close association has been reported with immune system dysfunctions [20], bladder cancer [21], neurotoxicity [22,23], and embryogenesis 
defects [24]. Although the toxicity mechanisms associated with heavy metals are still poorly understood, common mechanisms underlying their toxicity both as single entities or mixtures have been identified [25-28]. Reactive oxygen species (ROS) production and oxidative stress (OS) are major mechanisms leading to protein alteration, lipid peroxidation, and DNA damage [29-31]. Among the various heavy metals, $\mathrm{Hg}$ has drawn particular attention, as it is a major environmental pollutant whose levels have been continuously increasing in recent decades due to its increased release in the environment by industrial waste or fuel extraction procedures [32]. Noteworthy is the fact that $\mathrm{Hg}$ has been ranked among the 10 chemicals of greatest concern for human health risk by the World Health Organization (WHO) [33].

\section{Mercury Exposure and Toxicity}

The global burden of $\mathrm{Hg}$ toxicity represents a serious public health concern worldwide. $\mathrm{Hg}$ exists in the ecosystem in elementary, inorganic, and organic forms. Elemental mercury $\left(\mathrm{Hg}^{0}\right)$ is liquid and volatile at room temperature. This metal also exists as mercurous $\left(\mathrm{Hg}^{+}\right)$and mercuric $\left(\mathrm{Hg}^{2+}\right)$ cation and can form both inorganic and organic compounds, methylmercury $(\mathrm{MeHg})$ being the most widespread organic compound in the environment and the most important biologically [33,34]. MeHg is readily absorbed by the human body, which does not have an active excretion system for this element.

The different $\mathrm{Hg}$ molecular species can be environmentally as well as biologically converted into each other in soil, water, and air, due to their peculiar geo-biochemical cycle (Figure 1) as well as in our body. In aquatic sediments, a small fraction of $\mathrm{Hg}^{2+}$ is converted to organic forms by several kinds of anaerobic microorganisms which [35] enter the food chain through the contamination of fish and shellfish. Here $\mathrm{Hg}$ undergoes a process of bioaccumulation and biomagnification along the aquatic food chain until it reaches humans [36]. Conversely, $\mathrm{Hg}$ inhaled in elemental form or introduced orally in the form of $\mathrm{MeHg}$, undergoes oxidation by catalase or demethylation in the liver $[37,38]$. Of the various sources of mercury contamination, food is certainly the most important in the general population. Other sources of contact with mercury affecting a wider range of individuals may be thermometers, batteries and some types of vaccines [39], which are responsible for possible accidental intoxications [40]. Although $\mathrm{Hg}^{0}$ and inorganic compounds are potentially dangerous to human health, exposure to these forms is generally limited to individual occupational exposure. However, $\mathrm{Hg}^{0}$ can be released from dental amalgams, thus representing one of the main sources of chronic exposure to low levels of $\mathrm{Hg}$ in humans [41,42].

The molecular mechanisms underlying Hg-induced cytotoxicity are complex, with likely contributions from genetic susceptibility [43] and exposure to the different molecular forms of this metal.

This metal, endowed with a high binding capacity to the sulfhydryl (SH) group, reacts with small molecular weight thiols, including alpha lipoic acid, and glutathione (GSH), thus impairing key metabolic pathways as well as the antioxidant defense system $[44,45]$. In this respect, $\mathrm{Hg}$ binding to selenium-containing proteins inhibits enzymes such as glutathione peroxidase and hinders the restoration of intracellular redox balance, thus worsening OS [46]. Interestingly, the genetic predisposition to the development of antioxidant system dysfunctions is associated with polymorphisms that determine a greater susceptibility to $\mathrm{MeHg}$ toxicity $[43,47,48]$. Specific pathways such as that of thioredoxin are also inhibited by $\mathrm{Hg}$ [49-51]. 


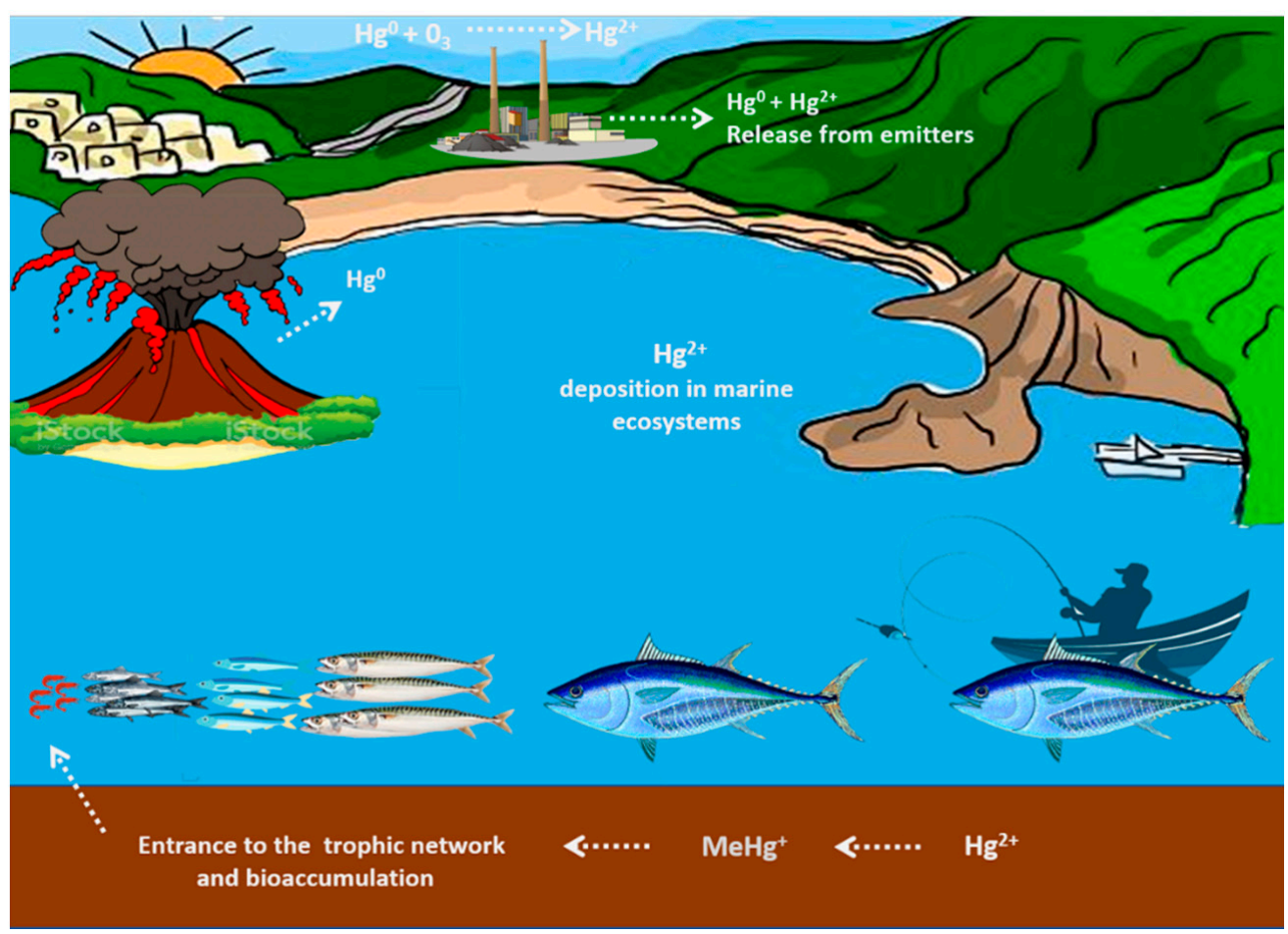

Figure 1. The $\mathrm{Hg}$ biogeochemical cycle. $\mathrm{Hg}$ pollution of the environment mainly results from natural sources such as volcanic activity and fossil fuels as well as human industrial activities. $\mathrm{Hg}$ exists in the ecosystem in elementary, inorganic, and organic forms. These different species can be environmentally as well as biologically converted into each other in soil, air and especially water. In aquatic sediments, inorganic $\mathrm{Hg}$ is converted into its organic forms, mainly methylmercury, by microorganisms. This form enters the trophic network via plankton and it accumulates in the passage through small to carnivorous fish at the top of the food chain, via the process of biomagnification, reaching humans through contaminated fish.

In addition, by reacting with crucial cysteine (Cys) residues, $\mathrm{Hg}$ may interact with cellular proteins, thus altering and inhibiting their enzymatic and structural functions and potentially leading to severe dysfunction in cellular activities [52]. In particular, $\mathrm{Hg}$ inhibitory activity on the glycolytic enzymes hexokinase and phosphofructokinase has been reported [53]. Also, membrane proteins are modified by $\mathrm{Hg}$, including tubulin [54] and erythrocyte (RBC) band 3 and 4.1 and 4.2 proteins [55].

An additional mechanism of $\mathrm{Hg}$ toxicity is the induction of mitochondrial dysfunction affecting the activity of F1-F0-ATPase [56], causing oxidative phosphorylation and electron transport defects. This can in turn increase ROS production [57] and redox homeostasis disruption [58]. Furthermore, the carnitine/acylcarnitine transporter has been identified as a possible target of $\mathrm{Hg}$ toxicity in mitochondria [59].

Mercury toxicity is also associated with an increase in intracellular $\mathrm{Ca}^{2+}$ due to both an increase in the influx of $\mathrm{Ca}^{2+}$ from the extracellular environment and an increase in the mobilization of intracellular reserves [60]. This effect on calcium homeostasis, associated with the effect of calcium increase due to OS, is responsible for the activation of proteases, lipases, and endonucleases. Figure 2 shows a simplified diagram of the main mechanisms of $\mathrm{Hg}$ toxicity. 


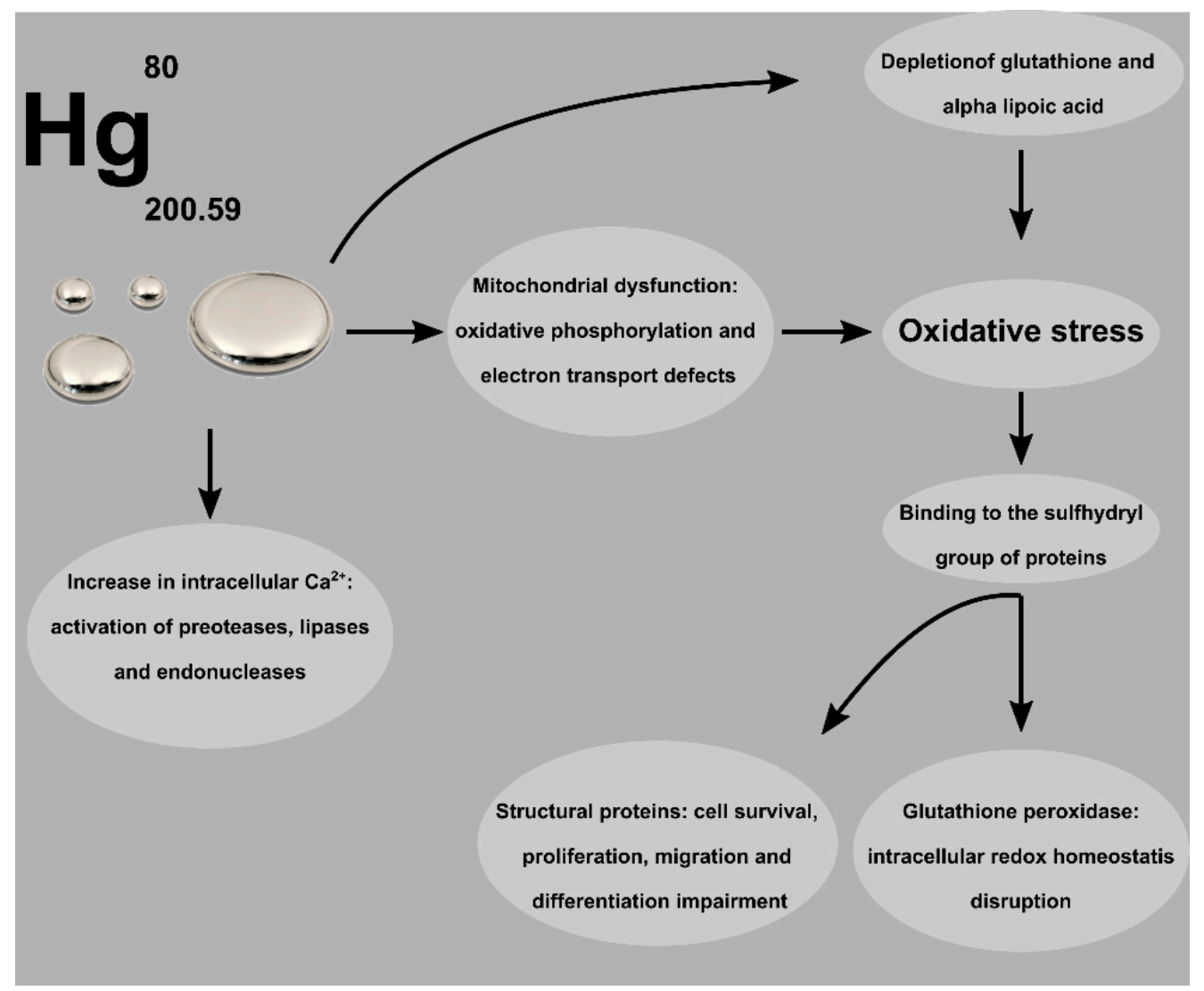

Figure 2. Mechanisms of toxicity associated with $\mathrm{Hg}$ exposure, most of which lead to oxidative stress.

\section{Acute Poisoning and Long-Term Toxicity}

The health risk for mankind following $\mathrm{Hg}$ exposure has been well documented by a long series of epidemiological and experimental studies. $\mathrm{Hg}$ poisoning is usually caused by ingestion or inhalation of its vapors. Acute mercury poisoning can cause various disorders, among which acrodynia is typical [61]. Other manifestations of mercury poisoning are pain in the extremities, neurological disorders such as ataxia, and confusional states (cardiovascular effects such as tachycardia and hypertension), and other non-specific symptoms such as fever, flu-like syndromes, skin rash, nausea, vomiting, and diarrhea [40,62,63]. A delay in treatment can cause serious consequences, such as pneumonitis, renal tubular necrosis and neurological dysfunction [64].

The intoxication by the organic compound $\mathrm{MeHg}$ has been associated with the tragedy of Minamata (Japan) in the $50 \mathrm{~s}$. The discharge of this compound in the gulf adjacent to the city caused a serious intoxication of the entire population [65]. The intoxication caused mental disorders, paralysis, coma, and death within a few weeks of the first symptoms [66]. A congenital form of the disease can be transmitted to the fetus during pregnancy causing delayed psychomotor development in infants [67]. This tragic event however has led to a deeper understanding of the mechanisms of MeHg toxicity. Although the mechanism underlying the tissue-selective vulnerability of the central nervous system (CNS) by MeHg remains to be elucidated, post-mortem studies of the above-mentioned mercury intoxication have shown petechial hemorrhages and cerebral edema, suggesting damage to the blood-brain barrier or a general involvement of vascular dysfunction $[58,68]$. These observations have been confirmed by the finding of a long-term increased incidence of hypertension and myocardial ischemia in the population living in the neighboring areas of Minamata [69].

Numerous studies have shown that long-term exposure to even small amounts of $\mathrm{MeHg}$ also affects endothelial function [70,71]. Nowadays, it is widely accepted that $\mathrm{Hg}$ 
exposure may be a risk factor for cerebrovascular and cardiovascular diseases (CVD), even without typical symptoms of $\mathrm{Hg}$ intoxication [58,72].

\section{Mercury and Endothelial Dysfunction}

The correlation between $\mathrm{Hg}$ exposure and endothelial dysfunction was confirmed after follow-up studies on severe cases of poisoning, the first being that of Minamata in Japan, which highlighted various cardiovascular anomalies [58,73]. Endothelial cells are very vulnerable to $\mathrm{Hg}$-induced OS caused either by increasing the production of oxidative agents or by inducing a decrease in antioxidant activity [71,74]. The increase of OS induces, via various pathways, endothelial inflammation first and then endothelial dysfunction, ref. [73,75] followed by the development of atherosclerosis, thrombophilia diathesis, and risk of ischemic phenomena through vessel obstruction or vasospastic events [76]. Polymorphisms in genes involved in antioxidant activity in the populations exposed to mercury have been shown to be associated with $\mathrm{MeHg}$ retention and increased risk of myocardial infarction [76,77]. Another important mechanism of $\mathrm{Hg}$ toxicity on the endothelium is the reduction of nitric oxide (NO) levels [78]. NO is an important cellular signaling molecule, which plays a crucial role in endothelium physiology, synthesized from the amino acid L-arginine by nitric oxide synthase (NOS) isoforms, mainly in endothelial cells [79].

Reduced NO bioavailability, together with the Hg-induced increase in OS, predisposes to CVD, such as carotid atherosclerosis, myocardial infarction, coronary heart disease and hypertension $[80,81]$. Exposure to low concentrations of $\mathrm{Hg}$ in the rat tail artery caused an increase in vascular resistance, mediated by an increase in ROS production, the production of vasoconstrictor mediators and the reduction in the bioavailability of NO [82]. In particular, superoxide anion inactivates $\mathrm{NO}$ [83], a potent vasodilator, causing in turn vasoconstriction of arteries [84]. Acute $\mathrm{Hg}$ exposure also produced vasoconstriction in rat aortic rings by increasing ROS (via NADPH oxidase) and inhibition of NO production [85]. The chronic exposure to low concentrations of $\mathrm{Hg}$ produced similar effects: increased production of ROS, reduced bioavailability of $\mathrm{NO}$ and endothelial dysfunction in the mesenteric, coronary, and basilar arteries [82,86]. Hg-induced endothelial damage also involves vasoconstrictor proteinoids derived from the COX-2 pathway and plasma angiotensin-converting enzyme (ACE) [87]. Concomitant mechanisms associated with Hg-induced toxicity are decreased proliferation and migration of endothelial cells, activation of coagulation pathways by promoting platelet aggregation and activation of factor XIII [58]. Hg poisoning is thus associated with the risk of atherothrombotic diseases, including hypertension, cerebrovascular disease, acute myocardial infarction, and renal dysfunction [80,88-91]. The main organs to be damaged by endothelial dysfunction are therefore the heart, kidneys, and brain $[78,80,91]$. Vascular dysfunction is also related to the development of hypertension, which exponentially increases the aforementioned risks [90].

\section{Mercury and Hypertension}

Besides the traditional risk factors associated with hypertension (overweight/obesity, sedentary lifestyle, cigarette smoke and excess salt intake) environmental exposures to heavy metals may also play an important role $[92,93]$. The most important cohort studies addressed towards the risk of hypertension from $\mathrm{Hg}$ exposure are those that were performed on miners or populations particularly exposed to this heavy metal such as Eskimos, inhabitants of the Minamata region, workers and fish consumers. It was observed that $\mathrm{Hg}$ miners showed a significant increase in systolic blood pressure which correlated with lipid peroxidation and total OS and an increased risk of developing hypertension of about 50\% [94]. Other important studies have shown a close correlation between the $\mathrm{Hg}$ content in hair (a marker of $\mathrm{Hg}$ exposure) and the incidence of hypertension $[95,96]$. Other studies, in contrast, have correlated hypertension to the blood content of $\mathrm{Hg}$, repeatedly finding a close association between high levels and hypertension $[97,98]$. In addition to hypertension, $\mathrm{Hg}$ exposure is also associated with a reduction in heart rate variability. The 
latter predisposes to arrhythmias, ventricular fibrillation, sudden cardiac death, angina, myocardial infarction, CVD, and cerebrovascular accidents [99].

One of the main mechanisms through which both acute and chronic $\mathrm{Hg}$ intoxication leads to hypertension is the binding of $\mathrm{Hg}$ to the sulfhydryl group of S-adenosyl methionine. This bond causes inactivation of the enzyme catecholamine-O-methyl transferase (COMT) which uses S-adenosyl-methionine as a cofactor. Since this enzyme operates the inactivation by O-methylation of adrenaline, noradrenaline, and dopamine [90]. Its inactivation causes an increase in circulating catecholamines and a syndrome like a pheochromocytoma crisis. This syndrome is characterized by malignant hypertension in acute intoxication and increased urinary excretion of catecholamines in chronic $\mathrm{Hg}$ intoxication. Another mechanism associated with hypertension is $\mathrm{Hg}$ toxicity with regard to the kidney. This metal concentrates in the renal tubules and glomeruli causing proteinuria and renal fibrosis and failure [100]. Renal dysfunction contributes to water and sodium retention and ultimately to hypertension $[82,90,91]$. In fact, an increased risk of renal failure of $55 \%$ was observed in $\mathrm{Hg}$ miners compared to the general population [91].

\section{The Role of Erythrocytes in Hg-Induced Endothelium Dysfunction}

In this context, it is important to highlight the proposed role of RBC in endothelial dysfunction and the risk of CVD. In fact, an increasing body of data has recently been accumulated on the role of these cells in both hemostasis and coagulation. Based on these findings, Weisel et Litvinov [101] defined RBC as "the forgotten actor" in endothelial dysfunction, reviewing how both quantitative and qualitative changes could affect bleeding or thrombosis [101]. Among the observed alterations, phosphatidylserine (PS) exposure at the outside leaflet of the cellular membrane has been proposed as a candidate hallmark of increased proatherogenic and prothrombotic activity of these cells. Specifically, PS exposure facilitates RBC adhesion to the endothelium, contributing to clot formation [102,103]. Furthermore, microvesicles (MVs) formation also leads to increased pro-coagulating events [104]. The key role of extracellular vesicles from RBC in health, coagulopathy and therapy has been recently reviewed [105].

Mammalian RBC are anucleate cells, deformable thanks to the shape of a biconcave disc, also lacking all the intracellular organelles, and thus representing a simplified model for metabolism studies. Moreover, they are deeply sensitive cells and important health markers because they have a highly specialized and organized cell membrane, which interacts with inflammatory oxidizing agents and mediators, leading to a variety of structural changes that readily signal an abnormal situation $[106,107]$. Late enucleation of erythroblasts in mammals is considered an advantage in the investigation of particular aspects of these cells as it defines a starting point of an average aging process of 120 days until their elimination. Accordingly, RBC have been identified for use as a cellular aging model [108] as well as being markers of OS-related pathologies, including CVD [106,108]. In fact, RBC are particularly advantageous for the study of OS caused by the high tension of oxygen and the highly toxic free radicals derived from it. Interestingly, being endowed with a powerful antioxidant defense machinery, these cells significantly contribute to other blood cells as well as endothelium from the oxidative insult. However, if RBC reach highly inflamed tissues, such as endothelium with atherosclerotic lesions, their behavior shifts from the physiological activity of scavenger to the harmful role of ROS generator, inducing an oxidative microenvironment, thus worsening the endothelial dysfunction. Therefore, the antioxidant status of RBC might represent a marker in CVD [106,109].

Similarly, RBC have been proposed as a model for pharmacological and toxicological studies which explore mechanisms underlying heavy metal toxicity, including $\mathrm{Hg}$. The effect that toxic substances have on these cells is often omitted, underestimating the concept that blood is the major tissue in contact with exogenous molecules. Moreover, blood also acts as a vehicle of substances, which reach all tissues. As far as heavy metal toxicity is concerned, $\mathrm{RBC}$ are a preferential site for $\mathrm{Hg}$ accumulation, reaching in these cells a concentration 20 times higher than that found in plasma [110]. 
The direct toxicity effect of $\mathrm{Hg}$ on $\mathrm{RBC}$ has been amply investigated in the last few years, both in vivo and in vitro. In a recent review, Vianna et al. [111] discuss the available evidence on potential hematological effects of human mercury exposure, including lymphopenia, lymphocytosis, neutrophilia and basophilia. The possible occurrence of anemia associated with $\mathrm{Hg}$ exposure has also been reported [111,112], likely due to hemolysis [112-114], loss of blood from the direct effect on the gastrointestinal mucosa and apoptosis $[112,114]$. Similarly to apoptosis of nucleated cells, RBC may undergo programmed cell death, also called eryptosis $[115,116]$. Interestingly, both eryptosis and apoptosis of nucleated cells share the feature of externalization of PS [117]. This altered membrane asymmetry results in the erythrophagocytosis of aged $\mathrm{RBC}$, thus regulating the life span of circulating mature cells as well as removal of stressed/damaged RBC in pathological situations $[118,119]$.

In recent years, particular attention has been focused on the mechanisms promoting vascular dysfunction and thrombotic events as a consequence of Hg-induced RBC damage (Figure 3). In this respect, workers occupationally exposed to $\mathrm{Hg}$ vapor show increased blood concentration of the heavy metal, associated with significant alterations in the coagulation system [120]. Among suggested mechanisms underlying the cardiovascular effects of $\mathrm{Hg}$ exposure, alterations of membrane asymmetry, due to PS exposure, enhances RBC adhesion to the endhothelial cells and clot formation. Hg-mediated SH depletion inhibits flippase and activates scramblase, increasing protein adhesion expression on the external surface of the cell and thrombin production [101]. In fact, PS-bearing RBC and MVs provide a binding site for assembling the prothrombinase complex, leading to thrombin generation, thus stimulating the coagulative cascade even at low-dose $\mathrm{Hg}^{2+}$ exposure. Alterations of RBC membrane proteins, leading to changes in cell shape and deformability, were also reported to be pro-thrombotic factors [121]. Changes in RBC shape have indeed been reported after in vitro exposure to this metal [121,122]. The underlying mechanisms are, also in this case, linked to the ability of this metal to bind SH groups. In fact, GSH and metallothionein, rich in free SH groups, have a pivotal role in the maintenance of erythrocyte integrity (e.g., the cytoskeleton) and ionic/energy balance (e.g., $\mathrm{Na}^{2+} / \mathrm{K}^{+}-$ ATPase) with ATP depletion and increased calcium. These mechanisms lead to increased fragility of the RBC membrane and disruption and MVs liberation [101]. All together, these effects design $\mathrm{RBC}$ as an active contributor to the increase in thrombotic events associated with Hg intoxication (Figure 4) [121,123,124].

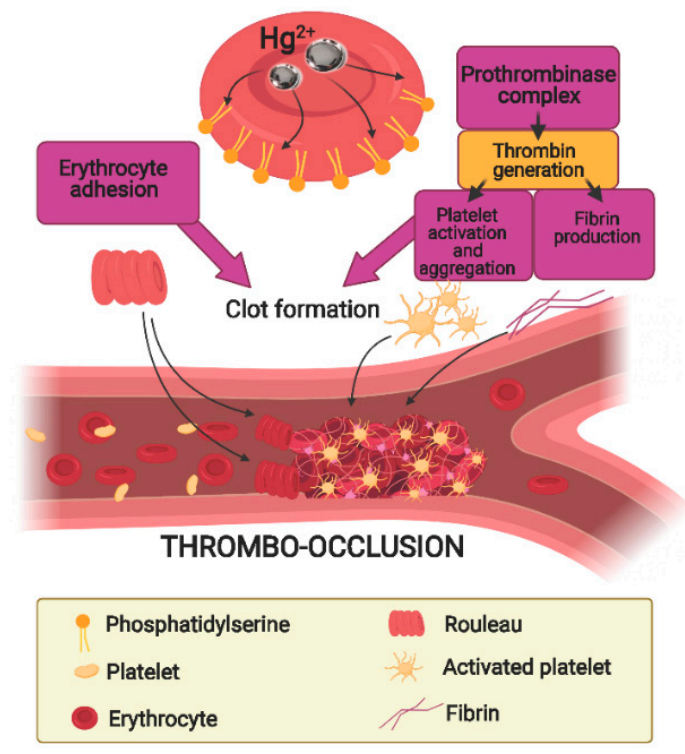

Figure 3. Hg-induced procoagulant activity in RBC. Hg-induced PS exposure on the outer surface of RBC enhances RBC adhesion to the endothelial cells. Moreover, PS-bearing RBC and MVs provide a site for assembling the prothrombinase complex, leading to thrombin generation and clot formation. 


\section{A}
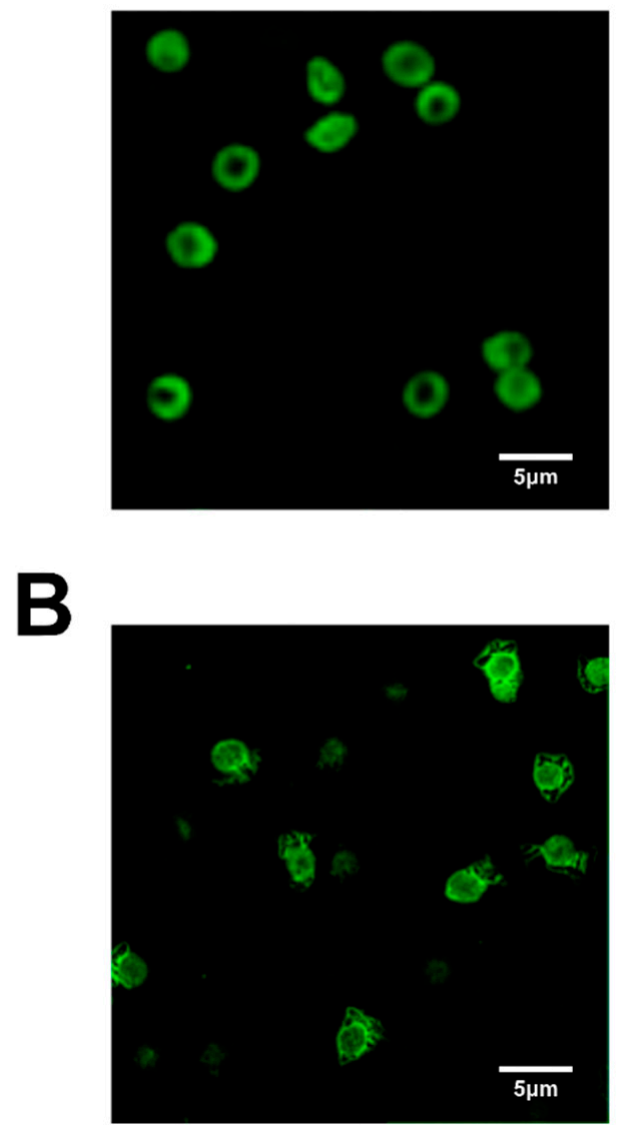

Figure 4. Morphological analysis of Hg-exposed RBC. Confocal Laser Scanning microscope imaging of intact $\mathrm{RBC}$ incubated in vitro in the presence of $20 \mu \mathrm{M} \mathrm{HgCl}_{2}$. At the end of incubation, cells were stained with Annexin V-FITC. (A) Untreated RBC; (B) $\mathrm{HgCl}_{2}$-treated RBC. Unpublished photos.

An additional key mechanism in which a role of RBC in the endothelial dysfunction has been suggested is NO production. Recent data point to RBC as key regulators of vasodilatation in peripheral tissue. These cells express the isoform eNOS and they display the ability to biosynthesize $\mathrm{NO}$ under oxygen deprivation, contributing to circulation homeostasis [125-128]. In this respect, $\mathrm{RBC}$ exposure to $\mathrm{HgCl}_{2}$ has been reported to decrease NOS activity, with consequent lowering of NO levels $[78,129]$. It is important to emphasise that the reported $\mathrm{Hg}$-induced damage to hemoglobin $(\mathrm{Hb})$ may also contribute to the decreased bioavailability of this key vasorelaxant molecule [130,131]. A tetrameric mercurized form of $\mathrm{Hb}$, supposed to be dysfunctional in physiological conformational changes crucial for the oxygenation/deoxygenation process, can be observed after RBC exposure to $\mathrm{Hg}^{2+}$ [55]. As discussed in the introduction, accessible Cys residues represent the preferential site of $\mathrm{Hg}$-protein interaction. It is worth noting, in this respect, that two critical Cys in position 93 of the beta-chains have been identified in $\mathrm{Hb}$ as $\mathrm{NO}$ ligand, playing a role in $\mathrm{Hb}$-mediated $\mathrm{NO}$ release [130]. Consequently, the alteration of Cys93, following $\mathrm{Hg}^{2+}$ interaction, might impair the $\mathrm{Hb}$-mediated regulation of blood flow, therefore representing one of the physiologically important manifestations of $\mathrm{Hg}$ poisoning in these cells, thus in turn affecting the cardiovascular system. As a result, based on these findings, RBC acquired the title of surrogate model for the study of $\mathrm{Hg}$-induced vascular dysfunction with full rights $[129,132,133]$. Finally, a different mechanism that may induce a decrease in $\mathrm{NO}$ availability is the generation of an oxidative microenvironment associated with $\mathrm{Hg}$ exposure. Indeed, it is well known that NO production usually decreases following endothelial dysfunction as well as under OS conditions $[129,134]$. In this context, when 
intact $\mathrm{RBC}$ are exposed in vitro to the presence of micromolar $\mathrm{HgCl}_{2}$ concentrations a dramatic increase in ROS generation is observed. ROS production is a late event and occurs subsequent to a decrease in the antioxidant thiol GSH, which significantly impairs the antioxidant defense system. In addition, an $\mathrm{Hg}$-induced nitrosative stress is also reported [131].

\section{Nutritional Aspects of Mercury Toxicity}

$\mathrm{Hg}$ is a metal that is not essential for nutrition, in that it is not an essential component of our body and is not involved in any metabolic pathway. However, as discussed in the introduction, diet represents one of the most important routes of chronic exposure to $\mathrm{Hg}$ in general populations [135]. The greatest risk comes from eating contaminated food, especially fish, which accumulate high $\mathrm{Hg}$ content, due to its peculiar biogeochemical cycle. The critical point for fish contamination is $\mathrm{Hg}$ cycling in the Aquatic Ecosystems, where this metal is converted into its organic forms, mainly $\mathrm{MeHg}$, by anaerobic microorganisms. This form, in turn, enters the aquatic trophic network via plankton and it tends to accumulate in biota in the passage through small fish, reaching its greatest concentration in carnivorous fish at the top of the food chain [36] due to the so-called process of biomagnification [136]. Importantly, only $\mathrm{Hg}$ biomagnifies in the food chain [137]. Following the water cycle, it pollutes surface and groundwater, involving crops, particularly cereals $[138,139]$. However, while there are foods responsible for $\mathrm{Hg}$ absorption in humans, on the other hand, there are foods containing bioactive compounds which are claimed to reduce its harmful health effects. Several naturally derived products have been tested as potential protective agents, either for prevention and/or as treatment against $\mathrm{Hg}$-induced cytotoxicity [140]. In this context, dietary components capable of chelating heavy metals are increasingly being used [141,142] including dietary fibers able to perform $\mathrm{Hg}$ chelation during gastric-intestinal transit [143].

In recent years a possible utilization of garlic (Allium sativium L.) as an important detoxifying agent against heavy metal toxicity, including $\mathrm{Hg}$, has been proposed [144]. This spice, indeed, widely used in preparing food as well as nutraceutical products, contains several organosulfur compounds, the most abundant being allicin [145] able to bind directly to $\mathrm{Hg}$. Interestingly, garlic is also rich in selenium, an essential mineral, which hinders $\mathrm{Hg}$ toxicity by forming inactive selenium-Hg complexes as well as by preventing ROS-induced cellular damage. It is well known indeed that selenium strengthens the antioxidant defense system [146], being a co-factor of antioxidant enzymes such as glutathione peroxidase [147]. In this respect, as discussed in the introduction, since a key mechanism underlying heavy metal toxicity is the impairment of the antioxidant defense system, vitamin C and E have been tested as potential protective agents [148-150]. Furthermore, several phytochemicals with scavenging properties have been proved to actively counteract the heavy metal-induced body burden and cellular biochemical alterations [151], including curcumin [152,153] and epigallocatechin gallate [154].

Finally, several studies have revealed the role of olive oil polyphenols in the prevention of $\mathrm{Hg}$ toxicity. There is general agreement, based on a large body of converging evidence, that the antioxidant fraction, including polyphenols, significantly contributes to the healthpromoting effect $[155,156]$ of this typical lipidic source of the Mediterranean Diet, a dietary habit associated with a low incidence of several pathologies [157,158], including CVD [159]. Among these compounds, hydroxytyrosol (3,4-dihydroxyphenyl- ethanol; HT) is mainly responsible for the antioxidant properties of this food due to efficient scavenger activity [160]. Besides its well-recognized anti-inflammatory and anticancer properties [161,162], HT ameliorates the harmful effects of toxic agents, including acrylamide [163-165] and acrolein [166-168] as well as the mycotoxin ochratoxin-A [169]. Moreover, recent data indicate that this dietary component is able to counteract the toxic effects linked to exposure of heavy metals, including $\mathrm{Hg}$. Mohan et al. reported that the ability of HT to promote the expression of nuclear factor erythroid 2-related factor 2 (Nrf2), which in turn elevates GSH levels, is crucial in ameliorating the neurotoxic effect of $\mathrm{MeHg}$ [170]. The protective effects 
of HT on the biochemical alterations induced in intact human RBC, subjected in vitro to treatment with $\mathrm{HgCl}_{2}$, has been recently investigated by our group [122,171]. The reported findings indicate that HT has the potential to modulate cytotoxicity and to counteract the OS induced in RBC by $\mathrm{Hg}$ treatment. An additional study also provides experimental evidence of the efficacy of HT in modulating the programmed suicidal death in these anucleate cells, also devoid of mitochondria and thus lacking any mitochondria-mediated apoptotic pathways. Cell preconditioning with an HT optimal dose, prior to exposure to $\mathrm{HgCl}_{2}$, causes a noteworthy decrease in PS-exposing $\mathrm{RBC}$, almost restoring ATP and GSH content [117]. Also of clinical importance is the finding that HT prevents Hg-induced RBC morphological alterations which potentially enhance the procoagulant activity of these cells, resulting in a contributing factor to $\mathrm{Hg}$-related thrombotic events. In recent years nutritional research as well as in vitro studies have focused on the effects of HT in the progression of atherosclerosis including the expression of adhesion molecules [172,173], a key mechanism implicated in plaque formation. Furthermore, HT inhibits in vitro LDL oxidation and counteracts the OS-induced endothelial dysfunction. The reported data on HT protective effects on $\mathrm{Hg}$-induced RBC alterations reveal that prevention of metal toxicity should be regarded as an additional mechanism responsible for the health-promoting potential of this dietary phenol on the cardiovascular system.

\section{Conclusions}

Human exposure to $\mathrm{Hg}$, in its elementary and molecular forms, may cause severe damage to the entire organism. If massive exposure is a rare event, mostly related to accidents or occupational exposure, chronic intoxication, due to low-level Hg exposure, is becoming a growing insidious concern for a larger portion of the population. In this respect, the pro-oxidant effect of this metal even at low-dose exposure has shifted the focus from a CNS-centred view to a more holistic view of Hg-induced health damage.

In this context, the data discussed in this review point to the involvement of the cardiovascular system as a major target of long-term toxicity, ranging from endothelial dysfunction to pro-coagulative transformation of RBC. Taken together, these effects expose all organs and systems to increased thrombotic risk. Accordingly, anti-vascular endothelial growth factor) monoclonal antibodies have been proposed, in preclinical settings based on the upregulation of these mediators in $\mathrm{Hg}$-induced endothelial dysfunctions. Moreover, the data on the morphological and metabolic alteration in RBC induced by $\mathrm{Hg}$ point to the key role of RBC in Hg-related endothelial dysfunction and let us propose potential alternative targets for the prevention of systemic damage induced by this heavy metal.

Chelation therapy remains the therapy of choice in massive exposure to heavy metals, including $\mathrm{Hg}$. The rationale for using thiol-based chelators lies in their ability to form a ring-like complex with the metal, facilitating its renal excretion. Chelation therapy, however, is not without risks since chelator agents are endowed with a degree of toxicity. In addition, the accurate choice of dosage and timing of administration is essential to avoid depletion of essential metals, with consequent worsening of the general condition of the patient.

The possibility of reducing heavy metal toxicity through bioactive dietary components has attracted great interest recently. Since contaminated food is the major source of chronic $\mathrm{Hg}$ exposure in the general population, fighting it on the same battlefield is an intriguing challenge. In addition to its primary role of providing adequate quantities of nutrients, a healthy diet is a vital factor in reducing morbidity and mortality from chronic diseases. In this context, fruit and vegetables contain thousands of phytochemicals, endowed with a variety of biological and pharmacological activities, which are able to strengthen biological functions with the aim of promoting human health and reducing the risk of disease. As far as metal toxicity is concerned, nutritional components, including vitamin $C$ and $E$ and selenium have been proved to be protective, representing an attractive tool to help our body to fight off the adverse effects of heavy metals. Moreover, data discussed in this review provide experimental evidence that antioxidant polyphenols, normally present in our diet, especially the Mediterranean, have the potential to modulate $\mathrm{Hg}$ toxicity, therefore 
representing ideal candidates for nutritional/nutraceutical strategies to counteract the clinical outcomes of chronic $\mathrm{Hg}$ exposure in humans, particularly related to CVD.

Author Contributions: Conceptualization, C.M.; writing-original draft preparation, R.N. and R.I.; writing-review and editing, C.M.; visualization, E.P. All authors have read and agreed to the published version of the manuscript.

Funding: This research received no external funding.

Conflicts of Interest: The authors declare no conflict of interest.

$\begin{array}{ll}\text { Abbreviations } \\ \text { ACE } & \text { Angiotensin-converting enzyme } \\ \text { COMT } & \text { Catecholamine-O-methyl transferase } \\ \text { CVD } & \text { Cardiovascular diseases } \\ \text { Cys } & \text { Cysteine } \\ \text { GSH } & \text { Glutathione } \\ \mathrm{Hb} & \text { Hemoglobin } \\ \mathrm{Hg} & \text { Mercury } \\ \mathrm{Hg} & \text { Elemental mercury } \\ \mathrm{Hg}{ }^{2+} & \text { Mercuric } \\ \mathrm{HT} & \text { Hydroxythyrosol } \\ \mathrm{MeHg} & \text { Methylmercury } \\ \mathrm{MVs} & \text { Microvesicles } \\ \mathrm{NO} & \text { Nitric oxide } \\ \mathrm{NOS} & \text { Nitric oxide synthase } \\ \mathrm{Nrf2} & \text { Nuclear factor erythroid 2-related factor 2 } \\ \mathrm{OS} & \text { Oxidative stress } \\ \mathrm{PS} & \text { Phosphatidylserine } \\ \text { RBC } & \text { Erythrocytes } \\ \text { ROS } & \text { Reactive oxygen species } \\ \text { SH } & \text { Sulfhydryl }\end{array}$

\section{References}

1. Jadhav, S.H.; Sarkar, S.N.; Patil, R.D.; Tripathi, H.C. Effects of Subchronic Exposure via Drinking Water to a Mixture of Eight Water-Contaminating Metals: A Biochemical and Histopathological Study in Male Rats. Arch. Environ. Contam. Toxicol. 2007, 53, 667-677. [CrossRef]

2. Jadhav, S.H.; Sarkar, S.N.; Aggarwal, M.; Tripathi, H.C. Induction of Oxidative Stress in Erythrocytes of Male Rats Subchronically Exposed to a Mixture of Eight Metals Found as Groundwater Contaminants in Different Parts of India. Arch. Environ. Contam. Toxicol. 2007, 52, 145-151. [CrossRef]

3. Carpenter, D.O.; Arcaro, K.; Spink, D.C. Understanding the Human Health Effects of Chemical Mixtures. Environ. Health Perspect. 2002, 110 (Suppl. 1), 25-42. [CrossRef] [PubMed]

4. Pimentel, D.; Cooperstein, S.; Randell, H.; Filiberto, D.; Sorrentino, S.; Kaye, B.; Nicklin, C.; Yagi, J.; Brian, J.; O’Hern, J.; et al. Ecology of Increasing Diseases: Population Growth and Environmental Degradation. Hum. Ecol. Interdiscip. J. 2007, 35, 653-668. [CrossRef] [PubMed]

5. Prüss-Ustün, A.; Vickers, C.; Haefliger, P.; Bertollini, R. Knowns and Unknowns on Burden of Disease Due to Chemicals: A Systematic Review. Environ. Health 2011, 10, 9. [CrossRef] [PubMed]

6. Basile, J.N.; Bloch, M.J. Exposure to Air Pollution Increases the Incidence of Hypertension and Diabetes in Black Women Living in Los Angeles. J. Clin. Hypertens. 2012, 14, 819-820. [CrossRef] [PubMed]

7. Lettieri, G.; Mollo, V.; Ambrosino, A.; Caccavale, F.; Troisi, J.; Febbraio, F.; Piscopo, M. Molecular Effects of Copper on the Reproductive System of Mytilus Galloprovincialis. Mol. Reprod. Dev. 2019. [CrossRef]

8. Naujokas, M.F.; Anderson, B.; Ahsan, H.; Aposhian, H.V.; Graziano, J.H.; Thompson, C.; Suk, W.A. The Broad Scope of Health Effects from Chronic Arsenic Exposure: Update on a Worldwide Public Health Problem. Environ. Health Perspect. 2013, 121, 295-302. [CrossRef]

9. Tollett, V.D.; Benvenutti, E.L.; Deer, L.A.; Rice, T.M. Differential Toxicity to Cd, Pb, and Cu in Dragonfly Larvae (Insecta: Odonata). Arch. Environ. Contam. Toxicol. 2009, 56, 77-84. [CrossRef]

10. Shargorodsky, J.; Curhan, S.G.; Henderson, E.; Eavey, R.; Curhan, G.C. Heavy Metals Exposure and Hearing Loss in US Adolescents. Arch. Otolaryngol. Head Neck Surg. 2011, 137, 1183-1189. [CrossRef] 
11. Wang, G.; Fowler, B.A. Roles of Biomarkers in Evaluating Interactions among Mixtures of Lead, Cadmium and Arsenic. Toxicol. Appl. Pharmacol. 2008, 233, 92-99. [CrossRef]

12. Payne, R.J.; Stevens, C.J.; Dise, N.B.; Gowing, D.J.; Pilkington, M.G.; Phoenix, G.K.; Emmett, B.A.; Ashmore, M.R. Impacts of Atmospheric Pollution on the Plant Communities of British Acid Grasslands. Environ. Pollut. 2011, 159, 2602-2608. [CrossRef]

13. Silva, R.L.B.; Barra, C.M.; Monteiro, T.C.d.N.; Brilhante, O.M. A study of groundwater contamination with organic fuels and potential public health impact in Itaguaí, Rio de Janeiro State, Brazil. Cad. Saude Publica 2002, 18, 1599-1607. [CrossRef] [PubMed]

14. Lettieri, G.; D’Agostino, G.; Mele, E.; Cardito, C.; Esposito, R.; Cimmino, A.; Giarra, A.; Trifuoggi, M.; Raimondo, S.; Notari, T.; et al. Discovery of the Involvement in DNA Oxidative Damage of Human Sperm Nuclear Basic Proteins of Healthy Young Men Living in Polluted Areas. Int. J. Mol. Sci. 2020, 21, 4198. [CrossRef] [PubMed]

15. Marsano, F.; Boatti, L.; Ranzato, E.; Cavaletto, M.; Magnelli, V.; Dondero, F.; Viarengo, A. Effects of Mercury on Dictyostelium Discoideum: Proteomics Reveals the Molecular Mechanisms of Physiological Adaptation and Toxicity. J. Proteome Res. 2010, 9 , 2839-2854. [CrossRef] [PubMed]

16. Maresca, V.; Lettieri, G.; Sorbo, S.; Piscopo, M.; Basile, A. Biological Responses to Cadmium Stress in Liverwort Conocephalum Conicum (Marchantiales). Int. J. Mol. Sci. 2020, 21, 6485. [CrossRef] [PubMed]

17. Nurchi, V.M.; Djordjevic, A.B.; Crisponi, G.; Alexander, J.; Bjørklund, G.; Aaseth, J. Arsenic Toxicity: Molecular Targets and Therapeutic Agents. Biomolecules 2020, 10, 235. [CrossRef]

18. Balali-Mood, M.; Naseri, K.; Tahergorabi, Z.; Khazdair, M.R.; Sadeghi, M. Toxic Mechanisms of Five Heavy Metals: Mercury, Lead, Chromium, Cadmium, and Arsenic. Front. Pharmacol. 2021, 12. [CrossRef] [PubMed]

19. Piscopo, M. Seasonal Dependence of Cadmium Molecular Effects on Mytilus Galloprovincialis (Lamarck, 1819) Protamine-like Protein Properties. Mol. Reprod. Dev. 2019, 86, 1418-1429. [CrossRef]

20. Lehmann, I.; Sack, U.; Lehmann, J. Metal Ions Affecting the Immune System. Met. Ions Toxicol. Eff. Interact. Interdepend. 2011, 8, 157-185.

21. Feki-Tounsi, M.; Olmedo, P.; Gil, F.; Khlifi, R.; Mhiri, M.-N.; Rebai, A.; Hamza-Chaffai, A. Cadmium in Blood of Tunisian Men and Risk of Bladder Cancer: Interactions with Arsenic Exposure and Smoking. Environ. Sci. Pollut. Res. Int. 2013, 20, 7204-7213. [CrossRef]

22. Hu, L.; Greer, J.B.; Solo-Gabriele, H.; Fieber, L.A.; Cai, Y. Arsenic Toxicity in the Human Nerve Cell Line SK-N-SH in the Presence of Chromium and Copper. Chemosphere 2013, 91, 1082-1087. [CrossRef] [PubMed]

23. Rai, N.K.; Ashok, A.; Rai, A.; Tripathi, S.; Nagar, G.K.; Mitra, K.; Bandyopadhyay, S. Exposure to As, Cd and Pb-Mixture Impairs Myelin and Axon Development in Rat Brain, Optic Nerve and Retina. Toxicol. Appl. Pharmacol. 2013, 273, 242-258. [CrossRef]

24. Fathallah, S.; Medhioub, M.N.; Kraiem, M.M. Sediment Contact Assay Using the Carpet Shell Clam, Ruditapes decussatus L., Embryos and Larvae for Assessing Contamination Levels of Four Sites in Tunisian Coast. Bull. Environ. Contam. Toxicol. 2013, 90, 611-615. [CrossRef]

25. Alloway, T.P. What Do We Know about the Long-Term Cognitive Effects of Iron-Deficiency Anemia in Infancy? Dev. Med. Child Neurol. 2013, 55, 401-402. [CrossRef]

26. Lettieri, G.; Notariale, R.; Ambrosino, A.; Di Bonito, A.; Giarra, A.; Trifuoggi, M.; Manna, C.; Piscopo, M. Spermatozoa Transcriptional Response and Alterations in PL Proteins Properties after Exposure of Mytilus Galloprovincialis to Mercury. Int. J. Mol. Sci. 2021, 22, 1618. [CrossRef]

27. Dopp, E.; Kligerman, A.D.; Diaz-Bone, R.A. Organoarsenicals. Uptake, Metabolism, and Toxicity. Organomet. Environ. Toxicol. 2010, 7, 231-265. [CrossRef]

28. Maresca, V.; Fusaro, L.; Sorbo, S.; Siciliano, A.; Loppi, S.; Paoli, L.; Monaci, F.; Karam, E.A.; Piscopo, M.; Guida, M.; et al. Functional and Structural Biomarkers to Monitor Heavy Metal Pollution of One of the Most Contaminated Freshwater Sites in Southern Europe. Ecotoxicol. Environ. Saf. 2018, 163, 665-673. [CrossRef] [PubMed]

29. Whittaker, M.H.; Wang, G.; Chen, X.-Q.; Lipsky, M.; Smith, D.; Gwiazda, R.; Fowler, B.A. Exposure to Pb, Cd, and As Mixtures Potentiates the Production of Oxidative Stress Precursors: 30-Day, 90-Day, and 180-Day Drinking Water Studies in Rats. Toxicol. Appl. Pharmacol. 2011, 254, 154-166. [CrossRef]

30. Wu, X.; Cobbina, S.J.; Mao, G.; Xu, H.; Zhang, Z.; Yang, L. A Review of Toxicity and Mechanisms of Individual and Mixtures of Heavy Metals in the Environment. Environ. Sci. Pollut. Res. Int. 2016, 23, 8244-8259. [CrossRef]

31. De Guglielmo, V.; Puoti, R.; Notariale, R.; Maresca, V.; Ausió, J.; Troisi, J.; Verrillo, M.; Basile, A.; Febbraio, F.; Piscopo, M. Alterations in the Properties of Sperm Protamine-like II Protein after Exposure of Mytilus Galloprovincialis (Lamarck 1819) to Sub-Toxic Doses of Cadmium. Ecotoxicol. Environ. Saf. 2019, 169, 600-606. [CrossRef] [PubMed]

32. Bjørklund, G.; Dadar, M.; Mutter, J.; Aaseth, J. The Toxicology of Mercury: Current Research and Emerging Trends. Environ. Res. 2017, 159. [CrossRef] [PubMed]

33. Raj, D.; Maiti, S. Sources, Toxicity, and Remediation of Mercury: An Essence Review. Environ. Monit. Assess. 2019, 191. [CrossRef] [PubMed]

34. Obrist, D.; Kirk, J.L.; Zhang, L.; Sunderland, E.M.; Jiskra, M.; Selin, N.E. A Review of Global Environmental Mercury Processes in Response to Human and Natural Perturbations: Changes of Emissions, Climate, and Land Use. Ambio 2018, 47, 116-140. [CrossRef]

35. Baldi, F. Microbial Transformation of Mercury Species and Their Importance in the Biogeochemical Cycle of Mercury. Met. Ions Biol. Syst. 1997, 34, 213-257. 
36. Qiu, Y.-W.; Wang, W.-X. Comparison of Mercury Bioaccumulation between Wild and Mariculture Food Chains from a Subtropical Bay of Southern China. Environ. Geochem. Health 2016, 38, 39-49. [CrossRef] [PubMed]

37. Berglund, M.; Lind, B.; Björnberg, K.A.; Palm, B.; Einarsson, O.; Vahter, M. Inter-Individual Variations of Human Mercury Exposure Biomarkers: A Cross-Sectional Assessment. Environ. Health 2005, 4, 20. [CrossRef] [PubMed]

38. Park, J.-D.; Zheng, W. Human Exposure and Health Effects of Inorganic and Elemental Mercury. J. Prev. Med. Public Health 2012, 45, 344-352. [CrossRef] [PubMed]

39. Clifton, J.C. Mercury Exposure and Public Health. Pediatr. Clin. N. Am. 2007, 54, 237.e1-237.e45. [CrossRef]

40. Kamensky, O.L.; Horton, D.; Kingsley, D.P.; Bridges, C.C. A Case of Accidental Mercury Intoxication. J. Emerg. Med. 2019, 56, 275-278. [CrossRef]

41. Jirau-Colón, H.; González-Parrilla, L.; Martinez-Jiménez, J.; Adam, W.; Jiménez-Velez, B. Rethinking the Dental Amalgam Dilemma: An Integrated Toxicological Approach. Int. J. Environ. Res. Public Health 2019, 16, 1036. [CrossRef]

42. Tibau, A.V.; Grube, B.D. Mercury Contamination from Dental Amalgam. J. Health Pollut. 2019, 9, 190612. [CrossRef]

43. Andreoli, V.; Sprovieri, F. Genetic Aspects of Susceptibility to Mercury Toxicity: An Overview. Int. J. Environ. Res. Public Health 2017, 14, 93. [CrossRef]

44. Hernández, L.E.; Sobrino-Plata, J.; Montero-Palmero, M.B.; Carrasco-Gil, S.; Flores-Cáceres, M.L.; Ortega-Villasante, C.; Escobar, C. Contribution of Glutathione to the Control of Cellular Redox Homeostasis under Toxic Metal and Metalloid Stress. J. Exp. Bot. 2015, 66, 2901-2911. [CrossRef]

45. Yang, L.; Zhang, Y.; Wang, F.; Luo, Z.; Guo, S.; Strähle, U. Toxicity of Mercury: Molecular Evidence. Chemosphere 2020, $245,125586$. [CrossRef] [PubMed]

46. Usuki, F.; Fujimura, M. Decreased Plasma Thiol Antioxidant Barrier and Selenoproteins as Potential Biomarkers for Ongoing Methylmercury Intoxication and an Individual Protective Capacity. Arch. Toxicol. 2016, 90, 917-926. [CrossRef]

47. Barcelos, G.R.M.; de Souza, M.F.; de Oliveira, A.Á.S.; Lengert, A.V.H.; de Oliveira, M.T.; Camargo, R.B.D.O.G.; Grotto, D.; Valentini, J.; Garcia, S.C.; Braga, G.Ú.L.; et al. Effects of Genetic Polymorphisms on Antioxidant Status and Concentrations of the Metals in the Blood of Riverside Amazonian Communities Co-Exposed to Hg and Pb. Environ. Res. 2015, 138, 224-232. [CrossRef]

48. Schläwicke Engström, K.; Strömberg, U.; Lundh, T.; Johansson, I.; Vessby, B.; Hallmans, G.; Skerfving, S.; Broberg, K. Genetic Variation in Glutathione-Related Genes and Body Burden of Methylmercury. Environ. Health Perspect. 2008, 116, 734-739. [CrossRef]

49. Carvalho, C.M.L.; Chew, E.-H.; Hashemy, S.I.; Lu, J.; Holmgren, A. Inhibition of the Human Thioredoxin System. A Molecular Mechanism of Mercury Toxicity. J. Biol. Chem. 2008, 283, 11913-11923. [CrossRef] [PubMed]

50. Al Bakheet, S.A.; Attafi, I.M.; Maayah, Z.H.; Abd-Allah, A.R.; Asiri, Y.A.; Korashy, H.M. Effect of Long-Term Human Exposure to Environmental Heavy Metals on the Expression of Detoxification and DNA Repair Genes. Environ. Pollut. 2013, 181, $226-232$. [CrossRef] [PubMed]

51. Kirkpatrick, M.; Benoit, J.; Everett, W.; Gibson, J.; Rist, M.; Fredette, N. The Effects of Methylmercury Exposure on Behavior and Biomarkers of Oxidative Stress in Adult Mice. Neurotoxicology 2015, 50, 170-178. [CrossRef] [PubMed]

52. Ynalvez, R.; Gutierrez, J.; Gonzalez-Cantu, H. Mini-Review: Toxicity of Mercury as a Consequence of Enzyme Alteration. Biometals 2016, 29, 781-788. [CrossRef] [PubMed]

53. Ramírez-Bajo, M.J.; de Atauri, P.; Ortega, F.; Westerhoff, H.V.; Gelpí, J.L.; Centelles, J.J.; Cascante, M. Effects of Cadmium and Mercury on the Upper Part of Skeletal Muscle Glycolysis in Mice. PLoS ONE 2014, 9, e80018. [CrossRef] [PubMed]

54. Choi, W.-S.; Kim, S.-J.; Kim, J.S. Inorganic Lead (Pb)- and Mercury (Hg)-Induced Neuronal Cell Death Involves Cytoskeletal Reorganization. Lab. Anim. Res. 2011, 27, 219-225. [CrossRef]

55. Piscopo, M.; Notariale, R.; Tortora, F.; Lettieri, G.; Palumbo, G.; Manna, C. Novel Insights into Mercury Effects on Hemoglobin and Membrane Proteins in Human Erythrocytes. Molecules 2020, 25, 3278. [CrossRef]

56. Nesci, S.; Trombetti, F.; Pirini, M.; Ventrella, V.; Pagliarani, A. Mercury and Protein Thiols: Stimulation of Mitochondrial F1FO-ATPase and Inhibition of Respiration. Chem. Biol. Interact. 2016, 260, 42-49. [CrossRef]

57. Stohs, S.J.; Bagchi, D. Oxidative Mechanisms in the Toxicity of Metal Ions. Free Radic. Biol. Med. 1995, 18, 321-336. [CrossRef]

58. Takahashi, T.; Shimohata, T. Vascular Dysfunction Induced by Mercury Exposure. Int. J. Mol. Sci. 2019, 20, 2435. [CrossRef]

59. Tonazzi, A.; Giangregorio, N.; Console, L.; Scalise, M.; La Russa, D.; Notaristefano, C.; Brunelli, E.; Barca, D.; Indiveri, C. Mitochondrial Carnitine/Acylcarnitine Transporter, a Novel Target of Mercury Toxicity. Chem. Res. Toxicol. 2015, 28, 1015-1022. [CrossRef]

60. Florea, A.-M.; Büsselberg, D. Toxic Effects of Metals: Modulation of Intracellular Calcium Homeostasis. Mater. Werkst. 2005, 36, 757-760. [CrossRef]

61. Bose-O'Reilly, S.; McCarty, K.M.; Steckling, N.; Lettmeier, B. Mercury Exposure and Children's Health. Curr. Probl. Pediatr. Adolesc. Health Care 2010, 40, 186-215. [CrossRef]

62. Lerch, M.; Bircher, A.J. Systemically Induced Allergic Exanthem from Mercury. Contact Dermat. 2004, 50, 349-353. [CrossRef]

63. Oz, S.G.; Tozlu, M.; Yalcin, S.S.; Sozen, T.; Guven, G.S. Mercury Vapor Inhalation and Poisoning of a Family. Inhal. Toxicol. 2012, 24, 652-658. [CrossRef] [PubMed]

64. Bernhoft, R.A. Mercury Toxicity and Treatment: A Review of the Literature. J. Environ. Public Health 2012, 2012, 460508. [CrossRef]

65. Eto, K. Pathology of Minamata Disease. Toxicol. Pathol. 1997, 25, 614-623. [CrossRef]

66. Igata, A. Epidemiological and Clinical Features of Minamata Disease. Environ. Res. 1993, 63, 157-169. [CrossRef] [PubMed] 
67. Matsumoto, H.; Koya, G.; Takeuchi, T. Fetal Minamata Disease: A Neuropathological Study of Two Cases of Intrauterine Intoxication by a Methyl Mercury Compound. J. Neuropathol. Exp. Neurol. 1965, 24, 563-574. [CrossRef] [PubMed]

68. Winkler, E.A.; Bell, R.D.; Zlokovic, B.V. Central Nervous System Pericytes in Health and Disease. Nat. Neurosci. 2011, 14, 1398-1405. [CrossRef] [PubMed]

69. Yorifuji, T.; Kashima, S. Secondary Sex Ratio in Regions Severely Exposed to Methylmercury "Minamata Disease". Int. Arch. Occup. Environ. Health 2016, 89, 659-665. [CrossRef]

70. Kishimoto, T.; Oguri, T.; Abe, M.; Kajitani, H.; Tada, M. Inhibitory Effect of Methylmercury on Migration and Tube Formation by Cultured Human Vascular Endothelial Cells. Arch. Toxicol. 1995, 69, 357-361. [CrossRef]

71. Rajaee, M.; Sánchez, B.N.; Renne, E.P.; Basu, N. An Investigation of Organic and Inorganic Mercury Exposure and Blood Pressure in a Small-Scale Gold Mining Community in Ghana. Int. J. Environ. Res. Public Health 2015, 12, 10020-10038. [CrossRef]

72. Genchi, G.; Sinicropi, M.S.; Carocci, A.; Lauria, G.; Catalano, A. Mercury Exposure and Heart Diseases. Int. J. Environ. Res. Public Health 2017, 14, 74. [CrossRef]

73. Haybar, H.; Shahrabi, S.; Rezaeeyan, H.; Shirzad, R.; Saki, N. Endothelial Cells: From Dysfunction Mechanism to Pharmacological Effect in Cardiovascular Disease. Cardiovasc. Toxicol. 2019, 19, 13-22. [CrossRef]

74. Robitaille, S.; Mailloux, R.J.; Chan, H.M. Methylmercury Alters Glutathione Homeostasis by Inhibiting Glutaredoxin 1 and Enhancing Glutathione Biosynthesis in Cultured Human Astrocytoma Cells. Toxicol. Lett. 2016, 256, 1-10. [CrossRef]

75. Small, H.Y.; Migliarino, S.; Czesnikiewicz-Guzik, M.; Guzik, T.J. Hypertension: Focus on Autoimmunity and Oxidative Stress Free Radic. Biol. Med. 2018, 125, 104-115. [CrossRef] [PubMed]

76. Vassallo, D.V.; Wiggers, G.A.; Padilha, A.S.; Simões, M.R. Endothelium: A Target for Harmful Actions of Metals. Curr. Hypertens. Rev. 2020, 16, 201-209. [CrossRef] [PubMed]

77. de Oliveira, A.Á.S.; de Souza, M.F.; Lengert, A.V.H.; de Oliveira, M.T.; de Camargo, R.B.O.G.; Braga, G.Ú.L.; de Cólus, I.M.S.; Barbosa, F.; Barcelos, G.R.M. Genetic Polymorphisms in Glutathione (GSH-) Related Genes Affect the Plasmatic Hg/Whole Blood $\mathrm{Hg}$ Partitioning and the Distribution between Inorganic and Methylmercury Levels in Plasma Collected from a Fish-Eating Population. BioMed Res. Int. 2014, 2014, e940952. [CrossRef]

78. Omanwar, S.; Fahim, M. Mercury Exposure and Endothelial Dysfunction: An Interplay Between Nitric Oxide and Oxidative Stress. Int. J. Toxicol. 2015, 34, 300-307. [CrossRef]

79. Tousoulis, D.; Kampoli, A.-M.; Tentolouris, C.; Papageorgiou, N.; Stefanadis, C. The Role of Nitric Oxide on Endothelial Function. Curr. Vasc. Pharmacol. 2012, 10, 4-18. [CrossRef] [PubMed]

80. Salonen, J.T.; Seppänen, K.; Lakka, T.A.; Salonen, R.; Kaplan, G.A. Mercury Accumulation and Accelerated Progression of Carotid Atherosclerosis: A Population-Based Prospective 4-Year Follow-up Study in Men in Eastern Finland. Atherosclerosis 2000, 148, 265-273. [CrossRef]

81. Guallar, E.; Sanz-Gallardo, M.I.; van't Veer, P.; Bode, P.; Aro, A.; Gómez-Aracena, J.; Kark, J.D.; Riemersma, R.A.; Martín-Moreno, J.M.; Kok, F.J.; et al. Mercury, Fish Oils, and the Risk of Myocardial Infarction. N. Engl. J. Med. 2002, 347, 1747-1754. [CrossRef] [PubMed]

82. Wiggers, G.A.; Peçanha, F.M.; Briones, A.M.; Pérez-Girón, J.V.; Miguel, M.; Vassallo, D.V.; Cachofeiro, V.; Alonso, M.J.; Salaices, M. Low Mercury Concentrations Cause Oxidative Stress and Endothelial Dysfunction in Conductance and Resistance Arteries. Am. J. Physiol. Heart Circ. Physiol. 2008, 295, H1033-H1043. [CrossRef]

83. Rubanyi, G.M.; Vanhoutte, P.M. Superoxide Anions and Hyperoxia Inactivate Endothelium-Derived Relaxing Factor. Am. J. Physiol. 1986, 250, H822-H827. [CrossRef]

84. Katusic, Z.S.; Vanhoutte, P.M. Superoxide Anion Is an Endothelium-Derived Contracting Factor. Am. J. Physiol. 1989, 257, H33-H37. [CrossRef]

85. Lemos, N.B.; Angeli, J.K.; Faria, T.D.O.; Ribeiro Junior, R.F.; Vassallo, D.V.; Padilha, A.S.; Stefanon, I. Low Mercury Concentration Produces Vasoconstriction, Decreases Nitric Oxide Bioavailability and Increases Oxidative Stress in Rat Conductance Artery. PLoS ONE 2012, 7, e49005. [CrossRef]

86. Furieri, L.B.; Fioresi, M.; Junior, R.F.R.; Bartolomé, M.V.; Fernandes, A.A.; Cachofeiro, V.; Lahera, V.; Salaices, M.; Stefanon, I.; Vassallo, D.V. Exposure to Low Mercury Concentration in Vivo Impairs Myocardial Contractile Function. Toxicol. Appl. Pharmacol. 2011, 255, 193-199. [CrossRef]

87. Pecanha, F.M.; Wiggers, G.A.; Briones, A.M.; Perez-Giron, J.V.; Miguel, M.; Garcia-Redondo, A.B.; Vassallo, D.V.; Alonso, M.J.; Salaices, M. The Role of Cyclooxygenase (COX)-2 Derived Prostanoids on Vasoconstrictor Responses to Phenylephrine Is Increased by Exposure to Low Mercury Concentration. J. Physiol. Pharmacol. 2010, 61, 29-36.

88. Houston, M.C. The Role of Mercury and Cadmium Heavy Metals in Vascular Disease, Hypertension, Coronary Heart Disease, and Myocardial Infarction. Altern. Ther. Health Med. 2007, 13, S128-S133.

89. Magos, L.; Sparrow, S.; Snowden, R. The Comparative Renotoxicology of Phenylmercury and Mercuric Chloride. Arch. Toxicol. 1982, 50, 133-139. [CrossRef] [PubMed]

90. Torres, A.D.; Rai, A.N.; Hardiek, M.L. Mercury Intoxication and Arterial Hypertension: Report of Two Patients and Review of the Literature. Pediatrics 2000, 105, E34. [CrossRef] [PubMed]

91. Boffetta, P.; Sällsten, G.; Garcia-Gómez, M.; Pompe-Kirn, V.; Zaridze, D.; Bulbulyan, M.; Caballero, J.D.; Ceccarelli, F.; Kobal, A.B.; Merler, E. Mortality from Cardiovascular Diseases and Exposure to Inorganic Mercury. Occup. Environ. Med. 2001, 58, 461-466. [CrossRef] 
92. Yorifuji, T.; Tsuda, T.; Kashima, S.; Takao, S.; Harada, M. Long-Term Exposure to Methylmercury and Its Effects on Hypertension in Minamata. Environ. Res. 2010, 110, 40-46. [CrossRef]

93. Houston, M.C. Role of Mercury Toxicity in Hypertension, Cardiovascular Disease, and Stroke. J. Clin. Hypertens. 2011, 13, 621-627. [CrossRef] [PubMed]

94. Kobal, A.B.; Horvat, M.; Prezelj, M.; Briski, A.S.; Krsnik, M.; Dizdarevic, T.; Mazej, D.; Falnoga, I.; Stibilj, V.; Arneric, N.; et al. The Impact of Long-Term Past Exposure to Elemental Mercury on Antioxidative Capacity and Lipid Peroxidation in Mercury Miners. J. Trace Elem. Med. Biol. 2004, 17, 261-274. [CrossRef]

95. Fillion, M.; Mergler, D.; Sousa Passos, C.J.; Larribe, F.; Lemire, M.; Guimarães, J.R.D. A Preliminary Study of Mercury Exposure and Blood Pressure in the Brazilian Amazon. Environ. Health 2006, 5, 29. [CrossRef] [PubMed]

96. Bautista, L.E.; Stein, J.H.; Morgan, B.J.; Stanton, N.; Young, T.; Nieto, F.J. Association of Blood and Hair Mercury with Blood Pressure and Vascular Reactivity. WMJ 2009, 108, 250-252. [PubMed]

97. Pedersen, E.B.; Jørgensen, M.E.; Pedersen, M.B.; Siggaard, C.; Sørensen, T.B.; Mulvad, G.; Hansen, J.C.; Asmund, G.; Skjoldborg, H. Relationship between Mercury in Blood and 24-h Ambulatory Blood Pressure in Greenlanders and Danes. Am. J. Hypertens. 2005, 18, 612-618. [CrossRef]

98. Vupputuri, S.; Longnecker, M.P.; Daniels, J.L.; Guo, X.; Sandler, D.P. Blood Mercury Level and Blood Pressure among US Women: Results from the National Health and Nutrition Examination Survey 1999-2000. Environ. Res. 2005, 97, 195-200. [CrossRef]

99. Valera, B.; Dewailly, E.; Poirier, P. Cardiac Autonomic Activity and Blood Pressure among Nunavik Inuit Adults Exposed to Environmental Mercury: A Cross-Sectional Study. Environ. Health 2008, 7, 29. [CrossRef]

100. Kobal, A.B.; Flisar, Z.; Miklavcic, V.; Dizdarević, T.; Sesek-Briski, A. Renal Function in Miners Intermittently Exposed to Elemental Mercury Vapour. Arh. Hig. Rada Toksikol. 2000, 51, 369-380.

101. Weisel, J.W.; Litvinov, R.I. Red Blood Cells: The Forgotten Player in Hemostasis and Thrombosis. J. Thromb. Haemost. 2019, 17, 271-282. [CrossRef] [PubMed]

102. Zwaal, R.F.A.; Comfurius, P.; Van Deenen, L.L.M. Membrane Asymmetry and Blood Coagulation. Nature 1977, 268, 358-360. [CrossRef]

103. Closse, C.; Dachary-Prigent, J.; Boisseau, M.R. Phosphatidylserine-Related Adhesion of Human Erythrocytes to Vascular Endothelium. Br. J. Haematol. 1999, 107, 300-302. [CrossRef] [PubMed]

104. Sudnitsyna, J.; Skverchinskaya, E.; Dobrylko, I.; Nikitina, E.; Gambaryan, S.; Mindukshev, I. Microvesicle Formation Induced by Oxidative Stress in Human Erythrocytes. Antioxidants 2020, 9, 929. [CrossRef]

105. Thangaraju, K.; Neerukonda, S.N.; Katneni, U.; Buehler, P.W. Extracellular Vesicles from Red Blood Cells and Their Evolving Roles in Health, Coagulopathy and Therapy. Int. J. Mol. Sci. 2020, 22, 153. [CrossRef] [PubMed]

106. Massaccesi, L.; Galliera, E.; Corsi Romanelli, M.M. Erythrocytes as Markers of Oxidative Stress Related Pathologies. Mech. Ageing Dev. 2020, 191, 111333. [CrossRef]

107. Hsieh, C.; Prabhu, N.C.S.; Rajashekaraiah, V. Age-Related Modulations in Erythrocytes under Blood Bank Conditions. Transfus. Med. Hemother. 2019, 46, 257-266. [CrossRef] [PubMed]

108. Kaestner, L.; Minetti, G. The Potential of Erythrocytes as Cellular Aging Models. Cell Death Differ. 2017, 24, 1475-1477. [CrossRef]

109. Mohanty, J.G.; Nagababu, E.; Rifkind, J.M. Red Blood Cell Oxidative Stress Impairs Oxygen Delivery and Induces Red Blood Cell Aging. Front. Physiol. 2014, 5, 84. [CrossRef] [PubMed]

110. Zalups, R.K. Molecular Interactions with Mercury in the Kidney. Pharmacol. Rev. 2000, 52, 113-143. [PubMed]

111. Vianna, A.D.S.; Matos, E.P.D.; Jesus, I.M.D.; Asmus, C.I.R.F.; Câmara, V.D.M. Human Exposure to Mercury and Its Hematological Effects: A Systematic Review. Cad. Pública 2019, 35. [CrossRef] [PubMed]

112. Zolla, L.; Lupidi, G.; Bellelli, A.; Amiconi, G. Effect of Mercuric Ions on Human Erythrocytes. Relationships between Hypotonic Swelling and Cell Aggregation. Biochim. Biophys. Acta 1997, 1328, 273-280. [CrossRef]

113. De Palma, G.; Mariotti, O.; Lonati, D.; Goldoni, M.; Catalani, S.; Mutti, A.; Locatelli, C.; Apostoli, P. Toxicokinetics and Toxicodynamics of Elemental Mercury Following Self-Administration. Clin. Toxicol. 2008, 46, 869-876. [CrossRef]

114. Suwalsky, M.; Ungerer, B.; Villena, F.; Cuevas, F.; Sotomayor, C.P. $\mathrm{HgCl}_{2}$ Disrupts the Structure of the Human Erythrocyte Membrane and Model Phospholipid Bilayers. J. Inorg. Biochem. 2000, 81, 267-273. [CrossRef]

115. Lang, F.; Lang, K.S.; Lang, P.A.; Huber, S.M.; Wieder, T. Mechanisms and Significance of Eryptosis. Antioxid. Redox Signal. 2006, 8 , 1183-1192. [CrossRef] [PubMed]

116. Tortora, F.; Notariale, R.; Lang, F.; Manna, C. Hydroxytyrosol Decreases Phosphatidylserine Exposure and Inhibits Suicidal Death Induced by Lysophosphatidic Acid in Human Erythrocytes. Cell Physiol. Biochem. 2019, 53, 921-932. [CrossRef]

117. Officioso, A.; Alzoubi, K.; Lang, F.; Manna, C. Hydroxytyrosol Inhibits Phosphatidylserine Exposure and Suicidal Death Induced by Mercury in Human Erythrocytes: Possible Involvement of the Glutathione Pathway. Food Chem. Toxicol. 2016, 89, 47-53. [CrossRef]

118. Gottlieb, Y.; Topaz, O.; Cohen, L.A.; Yakov, L.D.; Haber, T.; Morgenstern, A.; Weiss, A.; Chait Berman, K.; Fibach, E.; MeyronHoltz, E.G. Physiologically Aged Red Blood Cells Undergo Erythrophagocytosis in Vivo but Not in Vitro. Haematologica 2012, 97, 994-1002. [CrossRef]

119. Arashiki, N.; Takakuwa, Y. Maintenance and Regulation of Asymmetric Phospholipid Distribution in Human Erythrocyte Membranes: Implications for Erythrocyte Functions. Curr. Opin. Hematol. 2017, 24, 167-172. [CrossRef] [PubMed] 
120. Wierzbicki, R.; Prażanowski, M.; Michalska, M.; Krajewska, U.; Mielicki, W.P. Disorders in Blood Coagulation in Humans Occupationally Exposed to Mercuric Vapors. J. Trace Elem. Exp. Med. 2002, 15, 21-29. [CrossRef]

121. Lim, K.-M.; Kim, S.; Noh, J.-Y.; Kim, K.; Jang, W.-H.; Bae, O.-N.; Chung, S.-M.; Chung, J.-H. Low-Level Mercury Can Enhance Procoagulant Activity of Erythrocytes: A New Contributing Factor for Mercury-Related Thrombotic Disease. Environ. Health Perspect. 2010, 118, 928-935. [CrossRef]

122. Tagliafierro, L.; Officioso, A.; Sorbo, S.; Basile, A.; Manna, C. The Protective Role of Olive Oil Hydroxytyrosol against Oxidative Alterations Induced by Mercury in Human Erythrocytes. Food Chem. Toxicol. 2015, 82, 59-63. [CrossRef] [PubMed]

123. Eisele, K.; Lang, P.A.; Kempe, D.S.; Klarl, B.A.; Niemöller, O.; Wieder, T.; Huber, S.M.; Duranton, C.; Lang, F. Stimulation of Erythrocyte Phosphatidylserine Exposure by Mercury Ions. Toxicol. Appl. Pharmacol. 2006, 210, 116-122. [CrossRef]

124. Maseko, P.B.; van Rooy, M.; Taute, H.; Venter, C.; Serem, J.C.; Oberholzer, H.M. Whole Blood Ultrastructural Alterations by Mercury, Nickel and Manganese Alone and in Combination: An Ex Vivo Investigation. Toxicol. Ind. Health 2021, 37, 98-111. [CrossRef]

125. Chen, L.Y.; Mehta, J.L. Evidence for the Presence of L-Arginine-Nitric Oxide Pathway in Human Red Blood Cells: Relevance in the Effects of Red Blood Cells on Platelet Function. J. Cardiovasc. Pharmacol. 1998, 32, 57-61. [CrossRef]

126. Kang, E.S.; Ford, K.; Grokulsky, G.; Wang, Y.B.; Chiang, T.M.; Acchiardo, S.R. Normal Circulating Adult Human Red Blood Cells Contain Inactive NOS Proteins. J. Lab. Clin. Med. 2000, 135, 444-451. [CrossRef] [PubMed]

127. Bhattacharya, S.; Chakraborty Patra, S.; Basu Roy, S.; Kahn, N.N.; Sinha, A.K. Purification and Properties of Insulin-Activated Nitric Oxide Synthase from Human Erythrocyte Membranes. Arch. Physiol. Biochem. 2001, 109, 441-449. [CrossRef] [PubMed]

128. Kleinbongard, P.; Dejam, A.; Lauer, T.; Rassaf, T.; Schindler, A.; Picker, O.; Scheeren, T.; Gödecke, A.; Schrader, J.; Schulz, R.; et al. Plasma Nitrite Reflects Constitutive Nitric Oxide Synthase Activity in Mammals. Free Radic. Biol. Med. 2003, 35, 790-796. [CrossRef]

129. Harisa, G.I.; Mariee, A.D.; Abo-Salem, O.M.; Attiaa, S.M. Erythrocyte Nitric Oxide Synthase as a Surrogate Marker for MercuryInduced Vascular Damage: The Modulatory Effects of Naringin. Environ. Toxicol. 2014, 29, 1314-1322. [CrossRef]

130. Gladwin, M.T.; Lancaster, J.R.; Freeman, B.A.; Schechter, A.N. Nitric Oxide's Reactions with Hemoglobin: A View through the SNO-Storm. Nat. Med. 2003, 9, 496-500. [CrossRef] [PubMed]

131. Ahmad, S.; Mahmood, R. Mercury Chloride Toxicity in Human Erythrocytes: Enhanced Generation of ROS and RNS, Hemoglobin Oxidation, Impaired Antioxidant Power, and Inhibition of Plasma Membrane Redox System. Environ. Sci. Pollut. Res. Int. 2019, 26, 5645-5657. [CrossRef]

132. Minetti, M.; Agati, L.; Malorni, W. The Microenvironment Can Shift Erythrocytes from a Friendly to a Harmful Behavior: Pathogenetic Implications for Vascular Diseases. Cardiovasc. Res. 2007, 75, 21-28. [CrossRef]

133. Harisa, G.I.; Alanazi, F.K.; El-Bassat, R.A.; Malik, A.; Abdallah, G.M. Protective Effect of Pravastatin against Mercury Induced Vascular Cells Damage: Erythrocytes as Surrogate Markers. Environ. Toxicol. Pharmacol. 2012, 34, 428-435. [CrossRef]

134. Saravanakumar, M.; Raja, B. Veratric Acid, a Phenolic Acid Attenuates Blood Pressure and Oxidative Stress in L-NAME Induced Hypertensive Rats. Eur. J. Pharmacol. 2011, 671, 87-94. [CrossRef]

135. Nunes, E.; Cavaco, A.; Carvalho, C. Exposure Assessment of Pregnant Portuguese Women to Methylmercury through the Ingestion of Fish: Cross-Sectional Survey and Biomarker Validation. J. Toxicol. Environ. Health A 2014, 77, 133-142. [CrossRef] [PubMed]

136. Yan, H.; Li, Q.; Yuan, Z.; Jin, S.; Jing, M. Research Progress of Mercury Bioaccumulation in the Aquatic Food Chain, China: A Review. Bull. Environ. Contam. Toxicol. 2019, 102, 612-620. [CrossRef] [PubMed]

137. Dsikowitzky, L.; Mengesha, M.; Dadebo, E.; de Carvalho, C.E.V.; Sindern, S. Assessment of Heavy Metals in Water Samples and Tissues of Edible Fish Species from Awassa and Koka Rift Valley Lakes, Ethiopia. Environ. Monit. Assess. 2013, 185, 3117-3131. [CrossRef]

138. Barkay, T.; Poulain, A.J. Mercury (Micro)Biogeochemistry in Polar Environments. FEMS Microbiol. Ecol. 2007, 59, $232-241$. [CrossRef] [PubMed]

139. Liu, J.-L.; Xu, X.-R.; Yu, S.; Cheng, H.; Peng, J.-X.; Hong, Y.-G.; Feng, X.-B. Mercury Contamination in Fish and Human Hair from Hainan Island, South China Sea: Implication for Human Exposure. Environ. Res. 2014, 135, 42-47. [CrossRef] [PubMed]

140. Kalender, S.; Uzun, F.G.; Demir, F.; Uzunhisarcıklı, M.; Aslanturk, A. Mercuric Chloride-Induced Testicular Toxicity in Rats and the Protective Role of Sodium Selenite and Vitamin E. Food Chem. Toxicol. 2013, 55, 456-462. [CrossRef]

141. Pal, R.; Rai, J.P.N. Phytochelatins: Peptides Involved in Heavy Metal Detoxification. Appl. Biochem. Biotechnol. 2010, 160, 945-963. [CrossRef] [PubMed]

142. Manini, P.; Panzella, L.; Eidenberger, T.; Giarra, A.; Cerruti, P.; Trifuoggi, M.; Napolitano, A. Efficient Binding of Heavy Metals by Black Sesame Pigment: Toward Innovative Dietary Strategies To Prevent Bioaccumulation. J. Agric. Food Chem. 2016, 64. [CrossRef]

143. Rowland, I.R.; Mallett, A.K.; Flynn, J.; Hargreaves, R.J. The Effect of Various Dietary Fibres on Tissue Concentration and Chemical Form of Mercury after Methylmercury Exposure in Mice. Arch. Toxicol. 1986, 59, 94-98. [CrossRef] [PubMed]

144. Mumtaz, S.; Ali, S.; Khan, R.; Shakir, H.A.; Tahir, H.M.; Mumtaz, S.; Andleeb, S. Therapeutic Role of Garlic and Vitamins C and E against Toxicity Induced by Lead on Various Organs. Environ. Sci. Pollut. Res. Int. 2020, 27, 8953-8964. [CrossRef]

145. Amagase, H.; Petesch, B.L.; Matsuura, H.; Kasuga, S.; Itakura, Y. Intake of Garlic and Its Bioactive Components. J. Nutr. 2001, 131, 955S-962S. [CrossRef] 
146. Ralston, N.V.C.; Ralston, C.R.; Raymond, L.J. Selenium Health Benefit Values: Updated Criteria for Mercury Risk Assessments. Biol. Trace Elem. Res. 2016, 171, 262-269. [CrossRef] [PubMed]

147. Eb, K. The Importance of Antioxidants Which Play the Role in Cellular Response against Oxidative/Nitrosative Stress: Current State. Nutr. J. 2016, 15. [CrossRef]

148. Rendón-Ramírez, A.; Cerbón-Solórzano, J.; Maldonado-Vega, M.; Quintanar-Escorza, M.; Calderón-Salinas, J. Vitamin-E Reduces the Oxidative Damage on $\delta$-aminolevulinic Dehydratase Induced by Lead Intoxication in Rat Erythrocytes. Toxicol. In Vitro Int. J. Publ. Assoc. BIBRA 2007, 21, 1121-1126. [CrossRef]

149. Figueroa-Méndez, R.; Rivas-Arancibia, S. Vitamin C in Health and Disease: Its Role in the Metabolism of Cells and Redox State in the Brain. Front. Physiol. 2015, 6, 397. [CrossRef] [PubMed]

150. Al-Bideri, A.W. Histopathological Study on the Effect of Antioxidants (Vitamin E and Selenium) in Hepatotoxicity Induced by Lead Acetate in Rats. Qadisiah Med. J. 2011, 7, 142-155.

151. Tortora, F.; Notariale, R.; Maresca, V.; Good, K.V.; Sorbo, S.; Basile, A.; Piscopo, M.; Manna, C. Phenol-Rich Feijoa Sellowiana (Pineapple Guava) Extracts Protect Human Red Blood Cells from Mercury-Induced Cellular Toxicity. Antioxidants 2019, 8, 220. [CrossRef]

152. Mohammad Abu-Taweel, G.; Al-Fifi, Z. Protective Effects of Curcumin towards Anxiety and Depression-like Behaviors Induced Mercury Chloride. Saudi J. Biol. Sci. 2021, 28, 125-134. [CrossRef] [PubMed]

153. Li, S.; Wang, X.; Xiao, Y.; Wang, Y.; Wan, Y.; Li, X.; Li, Q.; Tang, X.; Cai, D.; Ran, B.; et al. Curcumin Ameliorates Mercuric Chloride-Induced Liver Injury via Modulating Cytochrome P450 Signaling and Nrf2/HO-1 Pathway. Ecotoxicol. Environ. Saf. 2021, 208, 111426. [CrossRef] [PubMed]

154. Zwolak, I. Epigallocatechin Gallate for Management of Heavy Metal-Induced Oxidative Stress: Mechanisms of Action, Efficacy, and Concerns. Int. J. Mol. Sci. 2021, 22, 4027. [CrossRef] [PubMed]

155. Castro-Barquero, S.; Tresserra-Rimbau, A.; Vitelli-Storelli, F.; Doménech, M.; Salas-Salvadó, J.; Martín-Sánchez, V.; Rubín-García, M.; Buil-Cosiales, P.; Corella, D.; Fitó, M.; et al. Dietary Polyphenol Intake Is Associated with HDL-Cholesterol and A Better Profile of Other Components of the Metabolic Syndrome: A PREDIMED-Plus Sub-Study. Nutrients 2020, 12, 689. [CrossRef] [PubMed]

156. Piscopo, M.; Tenore, G.C.; Notariale, R.; Maresca, V.; Maisto, M.; de Ruberto, F.; Heydari, M.; Sorbo, S.; Basile, A. Antimicrobial and Antioxidant Activity of Proteins from Feijoa Sellowiana Berg. Fruit before and after in Vitro Gastrointestinal Digestion. Nat. Prod. Res. 2019, 34, 2607-2611. [CrossRef]

157. Martinez-Gonzalez, M.A.; Martin-Calvo, N. Mediterranean Diet and Life Expectancy; beyond Olive Oil, Fruits, and Vegetables. Curr. Opin. Clin. Nutr. Metab. Care 2016, 19, 401-407. [CrossRef]

158. Martínez-González, M.A.; Salas-Salvadó, J.; Estruch, R.; Corella, D.; Fitó, M.; Ros, E.; PREDIMED INVESTIGATORS. Benefits of the Mediterranean Diet: Insights From the PREDIMED Study. Prog. Cardiovasc. Dis. 2015, 58, 50-60. [CrossRef]

159. Martínez-González, M.A.; Gea, A.; Ruiz-Canela, M. The Mediterranean Diet and Cardiovascular Health. Circ. Res. 2019, 124, 779-798. [CrossRef]

160. Gorzynik-Debicka, M.; Przychodzen, P.; Cappello, F.; Kuban-Jankowska, A.; Marino Gammazza, A.; Knap, N.; Wozniak, M.; Gorska-Ponikowska, M. Potential Health Benefits of Olive Oil and Plant Polyphenols. Int. J. Mol. Sci. 2018, 19, 686. [CrossRef]

161. Bertelli, M.; Kiani, A.K.; Paolacci, S.; Manara, E.; Kurti, D.; Dhuli, K.; Bushati, V.; Miertus, J.; Pangallo, D.; Baglivo, M.; et al Hydroxytyrosol: A Natural Compound with Promising Pharmacological Activities. J. Biotechnol. 2020, 309, 29-33. [CrossRef] [PubMed]

162. Echeverría, F.; Ortiz, M.; Valenzuela, R.; Videla, L.A. Hydroxytyrosol and Cytoprotection: A Projection for Clinical Interventions. Int. J. Mol. Sci. 2017, 18, 930. [CrossRef] [PubMed]

163. Zhang, X.; Cao, J.; Jiang, L.; Geng, C.; Zhong, L. Protective Effect of Hydroxytyrosol against Acrylamide-Induced Cytotoxicity and DNA Damage in HepG2 Cells. Mutat. Res. 2009, 664, 64-68. [CrossRef]

164. Rodríguez-Ramiro, I.; Martín, M.Á.; Ramos, S.; Bravo, L.; Goya, L. Olive Oil Hydroxytyrosol Reduces Toxicity Evoked by Acrylamide in Human Caco-2 Cells by Preventing Oxidative Stress. Toxicology 2011, 288, 43-48. [CrossRef] [PubMed]

165. Troise, A.D.; Colantuono, A.; Fiore, A. Spray-Dried Olive Mill Wastewater Reduces Maillard Reaction in Cookies Model System. Food Chem. 2020, 323, 126793. [CrossRef]

166. Wu, X.; Li, C.; Mariyam, Z.; Jiang, P.; Zhou, M.; Zeb, F.; Haq, I.U.; Chen, A.; Feng, Q. Acrolein-Induced Atherogenesis by Stimulation of Hepatic Flavin Containing Monooxygenase 3 and a Protection from Hydroxytyrosol. J. Cell. Physiol. 2018, 234, 475-485. [CrossRef]

167. Zhu, L.; Liu, Z.; Feng, Z.; Hao, J.; Shen, W.; Li, X.; Sun, L.; Sharman, E.; Wang, Y.; Liu, J.; et al. Hydroxytyrosol Protects against Oxidative Damage by Simultaneous Activation of Mitochondrial Biogenesis and Phase II Detoxifying Enzyme Systems in Retinal Pigment Epithelial Cells. J. Nutr. Biochem. 2010, 21, 1089-1098. [CrossRef]

168. Xu, Y.; Wu, L.; Chen, A.; Xu, C.; Feng, Q. Protective Effects of Olive Leaf Extract on Acrolein-Exacerbated Myocardial Infarction via an Endoplasmic Reticulum Stress Pathway. Int. J. Mol. Sci. 2018, 19, 493. [CrossRef]

169. Crupi, R.; Palma, E.; Siracusa, R.; Fusco, R.; Gugliandolo, E.; Cordaro, M.; Impellizzeri, D.; De Caro, C.; Calzetta, L.; Cuzzocrea, S.; et al. Protective Effect of Hydroxytyrosol Against Oxidative Stress Induced by the Ochratoxin in Kidney Cells: In Vitro and in Vivo Study. Front. Vet. Sci. 2020, 7, 136. [CrossRef] 
170. Mohan, V.; Das, S.; Rao, S.B.S. Hydroxytyrosol, a Dietary Phenolic Compound Forestalls the Toxic Effects of MethylmercuryInduced Toxicity in IMR-32 Human Neuroblastoma Cells. Environ. Toxicol. 2016, 31, 1264-1275. [CrossRef]

171. Officioso, A.; Panzella, L.; Tortora, F.; Alfieri, M.L.; Napolitano, A.; Manna, C. Comparative Analysis of the Effects of Olive Oil Hydroxytyrosol and Its 5-S-Lipoyl Conjugate in Protecting Human Erythrocytes from Mercury Toxicity. Oxid. Med. Cell. Longev. 2018, 2018, 9042192. [CrossRef] [PubMed]

172. Manna, C.; Napoli, D.; Cacciapuoti, G.; Porcelli, M.; Zappia, V. Olive Oil Phenolic Compounds Inhibit Homocysteine-Induced Endothelial Cell Adhesion Regardless of Their Different Antioxidant Activity. J. Agric. Food Chem. 2009, 57, 3478-3482. [CrossRef] [PubMed]

173. De Souza, P.A.L.; Marcadenti, A.; Portal, V.L. Effects of Olive Oil Phenolic Compounds on Inflammation in the Prevention and Treatment of Coronary Artery Disease. Nutrients 2017, 9, 1087. [CrossRef] [PubMed] 